\title{
4. LOWER CRETACEOUS COAL-BEARING SEDIMENTS FROM PRYDZ BAY, EAST ANTARCTICA ${ }^{1}$
}

\author{
Brian R. Turner ${ }^{2}$ and Dianne Padley ${ }^{2}$
}

Drilling in the inner part of Prydz Bay on the East Antarctic continental shelf (Ocean Drilling Program Leg 119, Site 741) revealed the presence of a 100 -m-thick sequence of Lower Cretaceous coal-bearing sediments, buried beneath some $24 \mathrm{~m}$ of glacial debris (Fig. 1). The sediments contain spores and pollen indicating a Early Cretaceous (middle Albian) age (Truswell, this volume). Seismic evidence suggests that these sediments form part of a 2- to 3-km-thick subhorizontal sedimentary sequence that probably overlies Precambrian basement (Cooper et al., this volume). A major angular unconformity occurs within this thick sedimentary sequence on some seismic lines, with the older sediments predating continental breakup and the younger sediments, including the Lower Cretaceous coal-bearing sediments, postdating breakup (Cooper et al., this volume). The breakup has been dated as early Neocomian $(130 \mathrm{Ma})$ on the basis of the M10-M11 magnetic anomalies reported by Powell et al. (1988).

The succession consists of sandstone and siltstone with minor amounts of conglomerate and claystone, containing abundant but variable amounts of finely disseminated organic matter, carbonaceous plant material, and rare rootlets and coals up to $4 \mathrm{~cm}$ thick (Fig. 2) (more detailed descriptions and photographs can be found in Barron, Larsen, et al., 1989). The sandstones are coarse to fine grained, poorly sorted, immature, and composed of quartz, feldspar, garnet, biotite, and pyrite. Large grains and small granules of quartz and feldspar are scattered throughout most of the sandstones and some of the siltstones in the succession. The sandstones are locally cemented by carbonate and sharply, or less commonly gradationally, overlain by siltstone and claystone. Individual sandstones are 2-3 m thick and texturally may fine upward or rarely coarsen upward. The fining-upward sandstones have sharp or erosive bases and comprise two types: (1) those that overlie poorly defined coarsening-upward sequences of claystone and siltstone and consist predominantly of structureless, locally burrowed and bioturbated sandstone with weak lamination and ripple cross-lamination (Fig. 2, column 7) and (2) sandstones that are unrelated to the coarsening-upward sequences and consist of an erosively based, very coarse-grained, feldspathic sandstone with locally developed conglomerate (Fig. 2, column 4). These sandstones contain smallscale cross-bedding and are pale gray to white in color; they contain little organic matter or plant material and no burrowing or bioturbation. The lower $20-30 \mathrm{~cm}$, immediately above the erosion surface, consists of a clast-supported, carbonate-cemented conglomerate containing rounded to subangular clasts up to $1 \mathrm{~cm}$ long of quartz, feldspar, garnet, biotite, ilmenite, and pyrite. The coarsening-upward sandstones gradationally overlie coarseningupward sequences that crudely grade from claystone and silty claystone into siltstone (Fig. 2, column 6). The claystone and

${ }^{1}$ Barron, J., Larsen, B., et al., 1991. Proc. ODP, Sci. Results, 119: College Station, TX (Ocean Drilling Program).

2 Department of Geology, The University, Newcastle Upon Tyne, NE1 7RU, United Kingdom. (Turner, present address: University of Durham, Department of Geological Sciences, Science Laboratories, South Road, Durham, DH1 3LE, United Kingdom.) siltstone contain irregular, diffuse laminae and thin beds of coarser sand and silt. Although primary sedimentary structures and textures in the siltstones and claystones have been disrupted by burrowing, including some Planolites-like burrows and bioturbation, weak lamination and ripple cross-lamination are locally preserved. Some elongate plant fragments show imbrication, consistent with transport to the depositional site.

The absence of fossils other than plants and pollen, the presence of rootlets and coal, and the locally coarse, poorly sorted, immature nature of the sandstones argue for a terrestrial origin for the sediments, which were probably locally derived. The rapid variation in grain size of the clastics suggests a climatic influence or possibly structural control of the basin or source. There is no direct evidence of any marine influence on deposition, which took place on an extensively vegetated alluvial plain drained by laterally shifting, low-sinuosity, coarse bed load-dominated channels. Within this environment the siltstone and claystone were deposited under quiet-water reducing conditions, probably in shallow lakes and marshes located between the distributary channels. These conditions, which were conducive to burrowing and bioturbation, were interrupted periodically by influxes of coarser detritus from nearby channels during floods, possibly from crevassing. Channel shifting or crevassing led to the infilling of the lakes and the development of coarsening-upward sequences capped by organic-rich, minor mouth bar sandstones or fining-upward distributory channel sandstones that cut down through the mouth bar and interdistributary bay deposits. On abandonment the sandstones were overlain by overbank or backswamp siltstone and claystone. The abundant flora and reducing nature of the environment imply that the climate was wet and that soil conditions may have been suitable for the extensive growth of vegetation. However, apart from sporadic rootlets there is no evidence of seat earths or other paleosols to support the idea of extensive in-situ plant growth and the development of peat swamps. Early Cretaceous paleogeographic reconstructions place Prydz Bay at about $45^{\circ}-50^{\circ} \mathrm{S}$ (Smith et al., 1981; Jefferson, 1982), suggesting a cool to warm temperate climatic regime.

Petrographic analysis of selected samples shows that the clastic sediments contain abundant phytoclasts, dominated by inertinite mainly in low-semifusinite with sporadic high-semifusinite clasts. Only minor amounts of vitrinite occur, as irregularly shaped, reworked phytoclasts and indigenous wisps and stringers. Liptinitic macerals, comprising miospores and megaspores, are rare. The coal is composed entirely of collinite (structureless vitrinite), which probably occurs as thin lenses rather than discrete seams. The presence of structureless collinite tends to suggest that the plant material was washed in. Collinite is thought to be produced by the precipitation of dissolved organic matter in a gel form (Stach et al., 1982). The occurrence of small framboidal pyrite in the samples suggests early diagenesis of iron monosulfide (Berner et al., 1979). The organic matter is a type III kerogen with only a gas hydrocarbon potential (McDonald et al., this volume; Kvenvolden et al., this volume). However, as the sediments contain no appreciable amounts of reactive mac- 


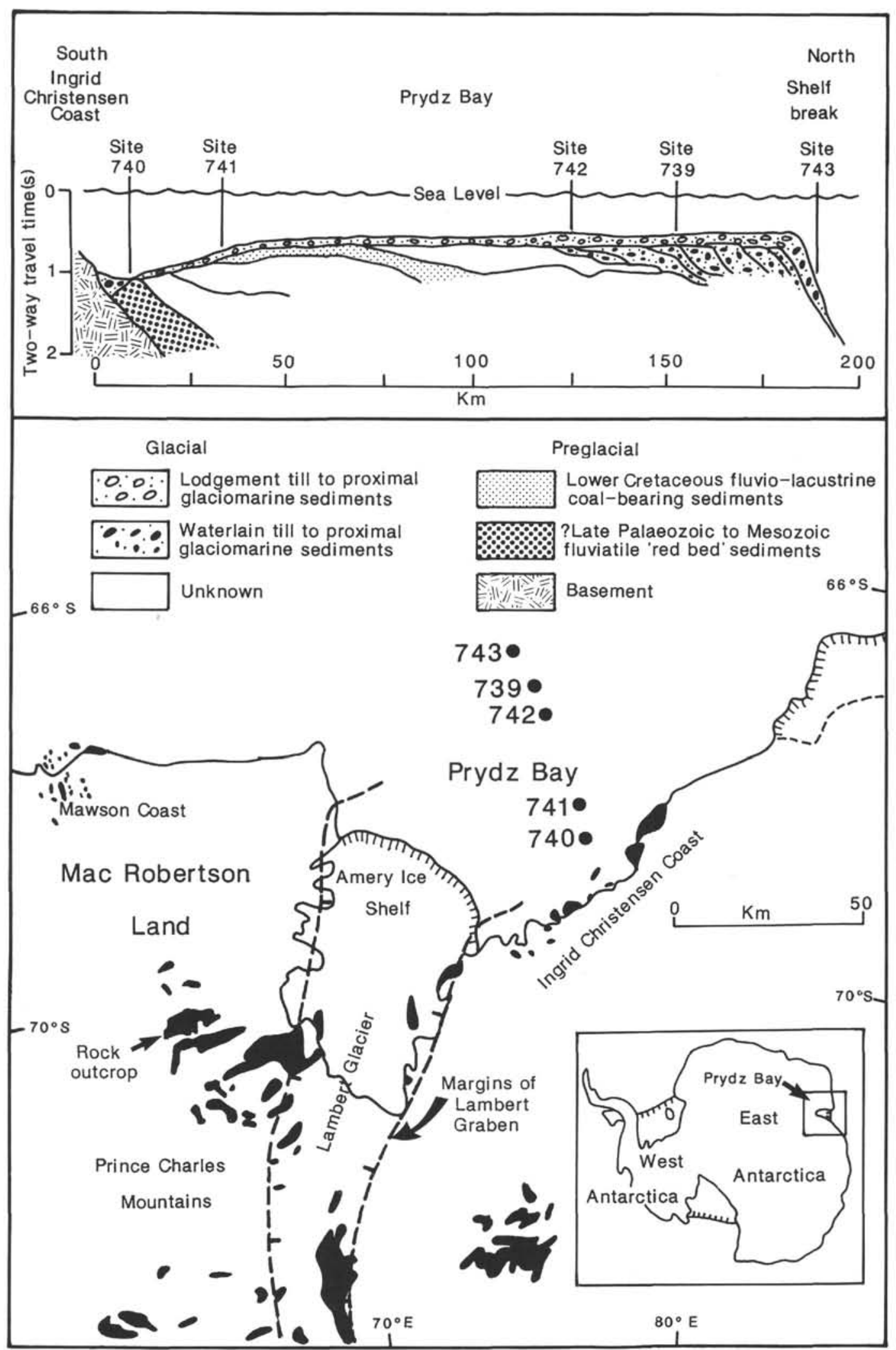

Figure 1. Generalized geologic cross section based on seismic and drill hole data and a map showing the location of Prydz Bay and the ODP drill sites. 

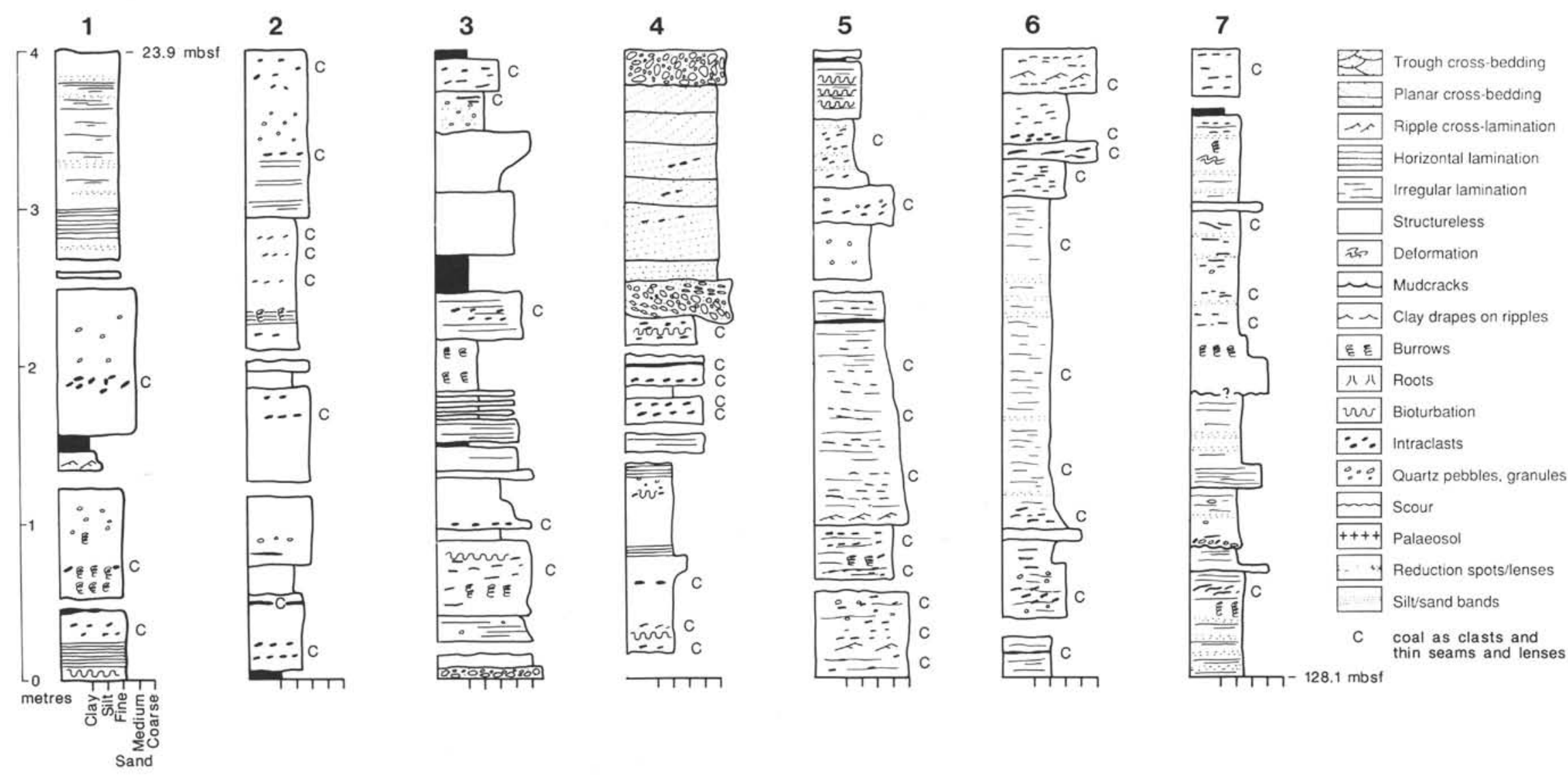

Figure 2. Composite lithologic section of Lower Cretaceous fluvio-lacustrine sediments from Site 741. 
erals, most of the organic matter may have been oxidized before deposition or reworked from older formations. The unoxidized nature of the pyrite shows that no postdepositional weathering has occurred.

The vitrinite reflectance of the samples falls consistently within the range $0.30 \%$ to $0.32 \%$, and the spore fluorescence color is yellow to yellow/orange. Thus, the sediments are immature. Evidence for the indigenous nature of the vitrinite is the form of the phytoclasts and the dark bitumen-stained halo around them, which is produced when humic acids are generated during diagenesis. The association of vitrinite with framboidal pyrite is yet another indication of the indigenous nature of the vitrinite. The spores indicate a higher maturity, equivalent to about $0.35 \%$ to $0.50 \%$ vitrinite reflectance. This could be due to the fact that the spores were reworked and are not indigenous to the sediment.

Rocks of Early Cretaceous age are not known from the adjacent onshore Amery Ice Shelf-Lambert Graben sector of the Antarctic continental margin or from other parts of coastal East Antarctica. However, piston coring close to the coastline of George V Land penetrated ?in-situ Lower Cretaceous siltstone, and palynological analysis of dredged seafloor samples and continental reconstructions predict the presence of nonmarine Lower Cretaceous rocks on the East Antarctic continental shelf (Truswell, 1982). Lower Cretaceous fluvio-lacustrine sediments containing thin coals and carbonaceous plant material are known from the Antarctic Peninsula area (Jefferson, 1982; Farquharson, 1982) but these form part of a volcaniclastic sequence that was deposited within an unstable forearc basin, in contrast to the more stable continental cratonic block of East Antarctica (Tingey, 1982). Similar sediments of Early Cretaceous age occur in the Mahanadi Basin in Peninsular India. This is placed adjacent to East Antarctica in most continental reconstructions (Smith and Hallam, 1970; Johnson et al., 1976) with the Lambert Graben directly opposite the Mahanadi Graben and Basin structure (Federov et al., 1982; Stagg, 1985). However, if the Site 741 sediments postdate rifting then the Mahanadi Basin may have been a considerable distance away at this point in time.

\section{REFERENCES}

Barron, J., Larsen, B., et al., 1989. Proc. ODP, Init. Repts., 119: College Station, TX (Ocean Drilling Program).

Berner, R. A., Baldwin, T., and Holdren, G. R., 1979. Authigenic iron sulphides as paleosalinity indicators. J. Sediment. Petrol., 49:13451350.

Farquharson, G. W., 1982. Lacustrine deltas in a Mesozoic alluvial sequence from Camp Hill, Antarctica. Sedimentology, 29:717-726.

Federov, L. V., Ravich, M. G., and Hofmann, J., 1982. Geological comparison of southeastern Peninsular India and Sri Lanka with a part of East Antarctica (Enderby Land, MacRobertson Land and Princess Elizabeth Land). In Craddock, C. (Ed.), Antarctic Geoscience: Madison, WI (Univ. Wisconsin Press), 73-78.

Jefferson, T. H., 1982. Fossil forests from the Lower Cretaceous of Alexander Island, Antarctica. Paleontology, 25:681-708.

Johnson, B. D., Powell, C. McA., and Veevers, J. J., 1976. Spreading history of the eastern Indian Ocean and Greater India's northward flight from Antarctica and Australia. Geol. Soc. Am. Bull., 87: 1560-1566.

Powell, C. McA., Roots, S. R., and Veevers, J. J., 1988. Pre-breakup continental extension in East Gondwanaland and the early opening of the eastern Indian Ocean. Tectonophysics, 155:261-283.

Smith, A. G., and Hallam, A., 1970. The fit of the southern continents. Nature, 225:139-144.

Smith, A. G., Hurley, A. M., and Briden, J. C., 1981. Phanerozoic Palaeocontinental World Maps: Cambridge (Cambridge Univ. Press).

Stach, E., Mackowsky, M.-Th., Teichmuller, M., Taylor, G. H., Chandra, D., and Teichmuller, R., 1982. Stach's Textbook of Coal Petrology (3rd ed.): Berlin (Gebruder Borntraeger).

Stagg, H.M.J., 1985. The structure and origin of Prydz Bay and MacRobertson Shelf, East Antarctica. Tectonophysics, 114:315-340.

Tingey, R. J., 1982. The geologic evolution of the Prince Charles Mountains-an Antarctic Archean cratonic block. In Craddock, C. (Ed.), Antarctic Geoscience: Madison (Univ. Wisconsin Press), 455-464.

Truswell, E. M., 1982. Palynology of seafloor samples collected by the 1911-14 Australian Antarctic expedition: implications for the geology of coastal East Antarctica. J. Geol. Soc. Aust., 29:343-356.

Date of initial receipt: 18 December 1989

Date of acceptance: 6 July 1990

Ms 119B-134 